\title{
Characteristics of phenotypes (clinical variants) of polycystic ovary syndrome in women of reproductive age
}

\author{
V.G. Syusyuka, M.Y. Sergienko, G.I. Makurina, O.A. Yershova, A.S. Chornenka \\ Zaporizhzhia State Medical University
}

\begin{abstract}
The objective: on the basis of a comprehensive examination of women of reproductive age to establish the frequency of phenotypes (clinical variants) of polycystic ovary syndrome (PCOS).

Materials and methods. 34 patients (main group) who complained of menstrual disorders and/or dermatopathies by recommendation of a dermatologist were examined. The control group is represented by 30 women without gynecological and somatic pathology. The mean age of women in the main group was $26,4 \pm 0,9$ years and $29,1 \pm 0,9$ years in the control group $(p>0,05)$. The age of women in the study groups ranged from 18 to 35 years. Patients underwent a comprehensive examination to assess the severity of hirsutism and the severity of acne, as well as the body mass index was determined. All women underwent ultrasound examination in the dynamics and quantitative assessment of the concentration of hormones in the blood plasma, namely cortisol, thyroid-stimulating hormone, prolactin, free testosterone and its index, androstenedione, dehydroepiandrosterone sulfate, $17 \alpha-\mathrm{OH}$-progesterone, sex hormone binding globulin. Variation-statistical processing of the results was carried out using the program «STATISTICA 13».

Results. The results of the conducted research show that 73,5\% had menstrual irregularities, and 52,9\% - infertility. Acne and hirsutism in every 3rd woman were combined and were diagnosed in $47,1 \%$ and $41,2 \%$ of women, respectively. Ultrasound signs of polycystic ovaries were found in $94,1 \%$ of patients according to the criteria for the diagnosis of PCOS, and in $88,2 \%$ - anovulation. According to the laboratory examination, hyperadrogenism was found in $55,9 \%$, which is confirmed by statistically significant $(\mathrm{p}<0,05)$ predominance in the main group compared with the control group of androstenedione, free testosterone and its index. In addition, it should be noted statistically significant $(\mathrm{p}<0,05)$ higher levels of $17 \alpha$-OH-progesterone and prolactin in the main group, but their indicators were within the reference values of the norm. Analyzing the frequency of phenotypes (clinical variants) of PCOS, it was found that phenotype A (classical) occurred in 32,4\%. Phenotype B (incomplete classical) was diagnosed in 14,7\%, and phenotype C (ovulatory) - only 8,8\%. The most often, namely in 15 (44,1\%) women with PCOS, the phenotype D (non-androgenic) was established. Conclusions. The results of the conducted research show that in women with PCOS clinical symptoms are characterized by menstrual dysfunction $(73,5 \%)$, infertility $(52,9 \%)$ and dermatopathies, namely acne $(47,1 \%)$ and hirsutism $(41,2 \%)$. According to the laboratory exanination, hyperadrogenism was found in $55,9 \%$, which is confirmed by statistically significant $(\mathrm{p}<0,05)$ predominance in the main group compared with the control group of androstenedione, free testosterone and its index. Among the clinical variants of PCOS, the non-androgenic phenotype (phenotype D) was the most often diagnosed, the frequency of it was 44,1\%. Classical (phenotype A) and incomplete classical (phenotype B) were found in $32,4 \%$ and $14,7 \%$, respectively. It should be noted that only $8,8 \%$ of women with PCOS are diagnosed with phenotype C (ovulatory).

Keywords: polycystic ovary syndrome, diagnosis, hormonal and ultrasound examination, phenotypes.
\end{abstract}

\section{Характеристика фенотипів (клінічних варіантів) синдрому полікістозних яєчників у жінок репродуктивного віку \\ В.Г. Сюсюка, М.Ю. Сергієнко, Г.І. Макуріна, О.А. Єршова, А.С. Чорненька}

Мета дослідження: на підставі комплексного обстеження жінок репродуктивного віку встановити частоту фенотипів (клінічних варіантів) синдрому полікістозних яєчників (СПКЯ).

Матеріали та методи. Обстежено 34 пацієнтки (основна група), які звернулися з приводу порушення менструального циклу та/або дерматопатій за рекомендацією дерматолога. Контрольна група представлена 30 жінками без гінекологічної та соматичної патології. Середній вік жінок основної групи становив $26,4 \pm 0,9$ року та $29,1 \pm 0,9$ року у групі контролю (р>0,05). Вік жінок у групах дослідження знаходився у межах $18-35$ років.

Пацієнткам проведено комплексне обстеження з оцінюванням вираженості гірсутизму та тяжкості перебігу акне, а також визначено індекс маси тіла. Усім жінкам виконано ультразвукове дослідження у динаміці та кількісне оцінювання концентрації гормонів у плазмі крові, а саме - кортизолу, тиреотропного гормону, пролактину, вільного тестостерону та його індексу, андростендіону, дегідроепіандростерону

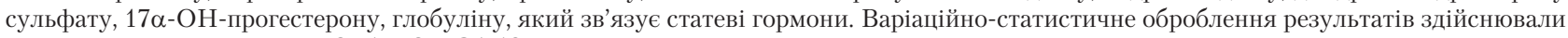
з використанням програми «STATISTICA 13».

Результати. За даними проведеного дослідження виявлено, що у 73,5\% жінок діагностовано порушення менструального циклу, а у $52,9 \%$ - безпліддя. Акне і гірсутизм у кожної третьої жінки мали поєднаний характер та діагностовані у $47,1 \%$ та $41,2 \%$ жінок відповідно. У 94,1\% пацієнток встановлені ехографічні ознаки полікістозу яєчників відповідно до критеріїв діагностики СПКЯ, а у 88,2\% - ановуляція. За даними лабораторних досліджень, гіперандрогенія встановлена у 55,9\%, що підтверджується статистично достовірним (р < 0,05) переважанням в основній групі порівняно з групою контролю рівнів андростендіону, вільного тестостерону та його індексу.

Крім того, слід відзначити і статистично достовірно $(\mathrm{p}<0,05)$ вищі рівні $17 \alpha$-ОН-прогестерону та пролактину в основній групі, однак їхні показники знаходились у межах референтних значень норми. Аналізуючи частоту фенотипів (клінічних варіантів) СПКЯ, встановлено, що фенотип А (класичний) виявлено у $32,4 \%$ пацієнток, фенотип В (неповний класичний) діагностовано у $14,7 \%$, а фенотип С (овуляторний) - лише у 8,8\%. Найчастіше, а саме - у 15 (44,1\%) жінок із СПКЯ, виявляли фенотип D (неандрогенний).

Заключення. Результати проведеного дослідження свідчать, що у жінок із СПКЯ клінічна симптоматика характеризується менструальною дисфункцією (73,5\%), безпліддям (52,9\%) та дерматопатіями, а саме - акне $(47,1 \%)$ і гірсутизмом (41,2\%). За даними лабораторних досліджень, гіперадрогенія встановлена у 55,9\%, що підтверджується статистично достовірним (р $<0,05)$ переважанням в основній групі порівняно з групою контролю рівня андростендіону, вільного тестостерону та його індексу.

Серед клінічних варіантів СПКЯ найчастіше діагностовано неандрогенний фенотип (фенотип D), частота якого становила 44,1\%. Класичний (фенотип А) та неповний класичний (фенотип В) встановлено у 32,4\% та 14,7\% жінок відповідно. Слід зазначити, що лише у 8,8\% жінок з СПКЯ діагностовано фенотип С (овуляторний).

Ключові слова: синдром полікістозних яєчників, діагностика, гормональне та ультразвукове дослідження, фенотипи. 


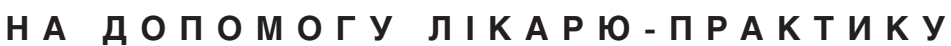

\section{Характеристика фенотипов (клинических вариантов) синдрома поликистозных яичников у женщин репродуктивного возраста \\ В.Г. Сюсюка, М.Ю. Сергиенко, Г.И. Макурина, Е.А. Ершова, А.С. Чёрненькая}

Цель исследования: на основании комплексного обследования женщин репродуктивного возраста установить частоту фенотипов (клинических вариантов) синдрома поликистозных яичников (СПКЯ).

Материалы и методы. Обследовано 34 пациентки (основная группа), которые обратились по поводу нарушения менструального цикла и/или дерматопатий по рекомендации дерматолога. Контрольная группа представлена 30 женщинами без гинекологической и соматической патологии. Средний возраст женщин основной группы составил $26,4 \pm 0,9$ года и $29,1 \pm 0,9$ года в группе контроля (р>0,05). Возраст женщин в группах исследования находился в пределах 18-35 лет.

Пациенткам проведено комплексное обследование с оценкой выраженности гирсутизма и тяжести течения акне, а также определение индекса массы тела. Всем женщинам выполнено ультразвуковое исследование в динамике и количественная оценка концентрации гормонов в плазме крови, а именно - кортизола, тиреотропного гормона, пролактина, свободного тестостерона и его индекса, андростендиона, дегидроэпиандростерона сульфата, $17 \alpha-\mathrm{OH}$-прогестерона, глобулина, связывающего половые гормоны. Вариационно-статистическую обработку результатов осуществляли с использованием программы «STATISTICA 13».

Peзультаты. По данным проведенного исследования выявлено, что у 73,5\% женщин диагностировали нарушения менструального цикла, а у $52,9 \%$ - бесплодие. Акне и гирсутизм у каждой третьей женщины имели сочетанный характер и диагностированы у $47,1 \%$ и $41,2 \%$ женщин соответственно. У 94,1\% пациенток установлены эхографические признаки поликистоза яичников в соответствии с критериями диагностики СПКЯ, а у 88,2\% - ановуляция. По данным лабораторных исследований, гиперандрогения установлена у $55,9 \%$, что подтверждается статистически достоверным $(\mathrm{p}<0,05)$ преобладанием в основной группе по сравнению с группой контроля уровней андростендиона, свободного тестостерона и его индекса.

Кроме того, следует отметить и статистически достоверно $(\mathrm{p}<0,05)$ более высокие уровни $17 \alpha$-ОН-прогестерона и пролактина в основной группе, однако их показатели находились в пределах референтных значений нормы. Анализируя частоту фенотипов (клинических вариантов) СПКЯ, установлено, что фенотип А (классический) выявлен у $32,4 \%$ пациенток, фенотип В (неполный классический) диагностирован у 14,7\%, а фенотип С (овуляторный) - только у 8,8\%. Чаще всего, а именно - у 15 (44,1\%) женщин с СПКЯ, выявляли фенотип $\mathrm{D}$ (неандрогенный).

Заключение. Результаты проведенного исследования свидетельствуют о том, что у женщин с СПКЯ клиническая симптоматика характеризуется менструальной дисфункцией (73,5\%), бесплодием (52,9\%) и дерматопатиями, а именно - акне (47,1\%) и гирсутизмом (41,2\%). По данным лабораторных исследований, гиперандрогения установлена у $55,9 \%$, что подтверждается статистически достоверным (р<0,05) преобладанием в основной группе по сравнению с группой контроля уровней андростендиона, свободного тестостерона и его индекса. Среди клинических вариантов СПКЯ чаще всего диагностировано неандрогенный фенотип (фенотип D), частота которого составила $44,1 \%$. Классический (фенотип А) и неполный классический (фенотип В) установлены у 32,4\% и 14,7\% женщин соответственно. Следует отметить, что только у 8,8\% женщин с СПКЯ диагностирован фенотип С (овуляторный).

Ключевые слова: синдром поликистозных яичников, диагностика, гормональное и ультразвуковое исследования, фенотипы.

$\mathrm{P}_{\mathrm{i}}$ olycystic ovary syndrome (PCOS) is a systemic pathology in which all parts of the endocrine system are disrupted, not just ovarian function. PCOS occurs in women of all ages, from puberty to menopause, involving almost all systems of the body [11]. PCOS is a very common endocrine disorder among women of reproductive age and in the general population is observed in $6-15 \%$ of women [8]. PCOS should not be considered as only a gynecological syndrome, as it can later become a prerequisite for the development of diseases such as diabetes, thromboembolism, hyperplastic processes in the endometrium, as well as psychosomatic disorders [6]. Thus, it reduces the quality of life of patients with PCOS [16]. The syndrome is an interdisciplinary disease that combines reproductive dysfunction with multiple metabolic disorders. The reasons for the development of PCOS are ambiguous and are currently being discussed; it is known that up to $50 \%$ of women have the genetic nature of PCOS. [9].

Modern approaches to the diagnosis of PCOS are based on the assessment of clinical and laboratory manifestations of hyperandrogenism, ovulatory dysfunction and changes in the ultrasound characteristics of the ovaries [10]. Given the nature of the complaints, the doctors of the first contact with patients suffering from PCOS, first of all, are obstetrician-gynecologists and dermatologists, and the so-called latent manifestations of the pathology expand the range of specialists. PCOS is usually detected in the early reproductive period, its clinical manifestations are extremely variable and can include: MC disorders on the background of oligo- / anovulation; infertility; polycystic ovaries according to the ultrasound; dermatopathies (acne, hirsutism, decreased hair growth in the scalp area); metabolic disorders: obesity, IR and, as a consequence, metabolic syndrome $[7,8,17]$. Patients with dermatopathies often turn to a dermatologist to solve this problem, so the doctor during the appointment should help the patient not only aesthetically, but also carefully get the medical history, examine the skin and, if necessary, refer to a specialist for further diagnosis, because the success in effectively help of women with PCOS is the joint work of a dermatologist, endocrinologist, gynecologist, etc. [6].

The main purpose of PCOS diagnosis is to determine the severity of clinical manifestations, the sources and pathogenesis of androgen hyperproduction, the impact on reproductive function, assessment of metabolic and cardiovascular risks [13]. A working group of experts from the National Institutes of Health (NIH) which was based on the methodology of evidence-based medicine (NIH Evidence-based Methodology Workshop), proposed to identify 4 phenotypes of PCOS (clinical variants). The 2018-year guideline «International evidence-based guideline for the assessment and management of polycystic ovary syndrome» confirmed the Rotterdam criteria and the relevance of determining clinical variants (phenotypes) of PCOS [2, 8, 9, 14]. The selected phenotypic form affects the capacity of differential diagnosis, lifelong risks, fertility and, respectively, management of the disease $[4,5]$. That is why a differentiated approach to the examination of patients with different phenotypes of PCOS allows to personify the therapy of this disease and to determine a set of preventive measures to improve the quality of life of women of reproductive age [1,10].

The objective: on the basis of a comprehensive examination of women of reproductive age to establish the frequency of phenotypes (clinical variants) of polycystic ovary syndrome.

\section{MATERIALS AND METHODS}

The main group of the research included 34 patients who complained of menstrual irregularities and/or dermatopathies by recommendation of a dermatologist. The control group is represented by 30 women without gynecological and somatic pathology. The mean age of women in the main group was $26,4 \pm 0,9$ years and $29,1 \pm 0,9$ years in the control group $(p>0,05)$. The age of women in the study groups ranged from 18 to 35 years. 


\section{Н А дОПОМОГУ Л ІКАРю- ПРАКТИКУ}

The results of the assessment of the concentration of hormones in the blood of women in the study groups

\begin{tabular}{|c|c|c|c|}
\hline Indicators & Main group & Control group & $\mathbf{P}$ \\
\hline Cortisol ( $\mu \mathrm{g} / \mathrm{DL})$ & $13,8 \pm 1,1$ & $12,9 \pm 0,9$ & $\mathrm{p}>0,05$ \\
\hline Thyroid-stimulating hormone $(\mu \mathrm{lU} / \mathrm{ml})$ & $1,8 \pm 0,2$ & $1,9 \pm 0,2$ & $p>0,05$ \\
\hline Prolactin (ng/ml) & $13,9 \pm 0,9$ & $11,0 \pm 0,5$ & $\mathrm{p}<0,05$ \\
\hline Free testosterone $(\mathrm{pg} / \mathrm{ml})$ & $4,1 \pm 0,6$ & $1,9 \pm 0,2$ & $\mathrm{p}<0,05$ \\
\hline Free testosterone index (\%) & $2,8 \pm 0,4$ & $1,3 \pm 0,2$ & $\mathrm{p}<0,05$ \\
\hline Androstenedione (ng/ml) & $3,2 \pm 0,2$ & $1,7 \pm 0,1$ & $p<0,05$ \\
\hline Dehydroepiandrosterone sulfate $(\mu \mathrm{g} / \mathrm{dl})$ & $192,9 \pm 14,7$ & $212,0 \pm 17,5$ & $p>0,05$ \\
\hline 17- $\alpha$-OH-progesterone (ng/ml) & $1,4 \pm 0,04$ & $1,0 \pm 0,1$ & $p<0,05$ \\
\hline Sex hormone binding globulin (nmol/l). & $62,2 \pm 5,1$ & $79,0 \pm 7,8$ & $p>0,05$ \\
\hline
\end{tabular}

The severity and distribution of hirsutism were determined by a modified Ferriman-Gallwey scale. To assess the severity of acne, women are consulted by a dermatologist. Body mass index (BMI) was determined, which was calculated by the formula (BMI = body weight $/$ height ${ }^{2}\left(\mathrm{~kg} / \mathrm{m}^{2}\right)$. According to the WHO, overweight was considered at a BMI of $25,0 \mathrm{~kg} / \mathrm{m}^{2}$, and obesity - from $30,0 \mathrm{~kg} / \mathrm{m}^{2}$.

In order to establish the diagnostic criteria that characterize PCOS, a comprehensive clinical and laboratory examination and ultrasound in the dynamics. Quantitative assessment of the concentration of hormones in blood plasma was performed by enzyme-linked immunosorbent assay to determine the level of cortisol - C $(\mu \mathrm{g} / \mathrm{DL})$, thyroid-stimulating hormone - TSH $(\mu \mathrm{IU} /$ $\mathrm{ml})$, prolactin - $\operatorname{Pr}(\mathrm{ng} / \mathrm{ml})$, free testosterone $-\mathrm{Tf}(\mathrm{pg} / \mathrm{ml})$ and its index (\%), androstenedione - An (ng/ml), dehydroepiandrosterone sulfate - DHEA-S $(\mu \mathrm{g} / \mathrm{dl})$ and $17-\alpha-\mathrm{OH}$-progesterone - 17-OHP $(\mathrm{ng} / \mathrm{ml})$, sex hormone binding globulin - SHBG (nmol/l). The research was performed on the third-fifth day of the menstrual cycle. Due to the fact that HA can be formed in hypothyroidism, hyperprolactinemia and adrenal dysfunction, women with relevant pathology were not included in the study group. Criteria for the diagnosis of PCOS are the presence of at least 2 of the 3 criteria: excessive activity or secretion of androgens (clinical and/or biochemical signs of HA); oligo- / anovulation; polycystic ovaries according to ultrasound of the pelvic organs (visualization of at least 12 follicles with a diameter of $2-9 \mathrm{~mm}$ in at least one ovary) [8].

Each woman was interviewed about the feasibility of additional research methods and consent was obtained. The research matches the modern requirements of moral and ethical norms regarding the rules of ICH/GCP, the Declaration of Helsinki (1964), the Council of Europe Conference on Human Rights and Biomedicine, as well as the provisions of legislative acts of Ukraine.

Variation-statistical processing of results was carried out using licensed standard packages of applications of multidimensional statistical analysis «STATISTICA 13».

\section{RESULTS}

According to the gynecological anamnesis, 73,5\% of women indicated menstrual irregularities and 52,9\% - infertility (Pic. 1). Clinical manifestations of menstrual dysfunction included, in particular, oligo- / amenorrhea. According to the ultrasound examination, $94,1 \%$ of patients had ultrasound signs of polycystic ovaries according to the criteria for the diagnosis of PCOS. The vast majority of women in the main group, namely $88,2 \%$, have anovulation.

Obesity is often accompanied by PCOS and is an additional significant factor in the formation of metabolic disorders and the subsequent development of serious complications [3]. 3 (8,8\%) women were diagnosed with grade I-II obesity and 4 women, which amounted to $11,8 \%$, were overweight.

Clinical manifestations of hyperandrogenism of women with PCOS are acne, hirsutism (enhanced hair growth in women of the male type - in androgen-dependent areas), seborrhea, androgenic

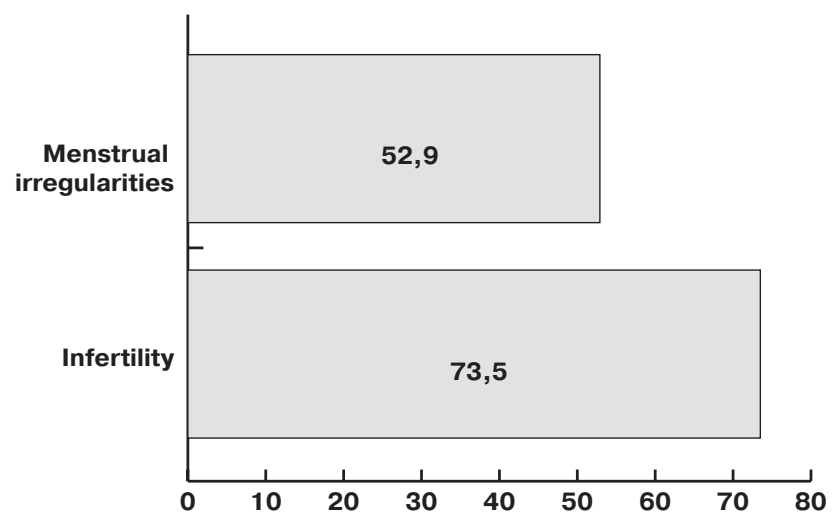

Pic. 1. The frequency of menstrual irregularities and infertility in the main group, $\%$

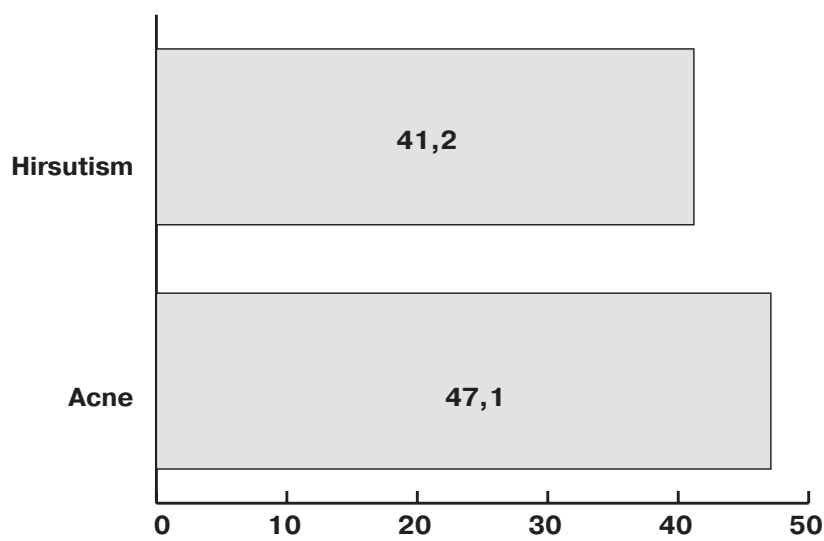

Pic. 2. The frequency of dermatopathies in the main group, $\%$

alopecia (baldness by male type), virilization (roughening of the voice, hypotrophy of the mammary glands, android body structure), etc. [8].

Thus, dermatopathies, namely acne and hirsutism, in our research were recorded in $47,1 \%$ and $41,2 \%$, cases, respectively, and in every 3rd woman were combined (Pic. 2).

According to laboratory examination, it was found that among women of the main group androstenedione levels were increased by more than half, namely in 19 (55,9\%). However, according to the assessment of the level of $\mathrm{Tf}$ and its index, an increase of these indicators was found only in $2(5,9 \%)$ and $5(14,7 \%)$ women, respectively. It should be noted that $62,5 \%$ of women with acne had elevated androgen levels. Differential diagnosis of HA in order to exclude other diseases primarily involves the exclusion of diseases 


\section{Н А ДОПОМОГУ Л І А РЮ-ПРАКТИКУ}

of thyroid gland, hyperprolactinemia and non-classical forms of congenital dysfunction of the adrenal cortex [8, 12]. Therefore, for the purpose of differential diagnosis in all patients with suspected PCOS, it is necessary to determine the level of prolactin, 17-OH-progesterone, thyroid-stimulating hormone, T4 free, antibodies to thyroglobulin, antibodies to peroxidase to exclude thyroid pathology [15]. The main criterion for the diagnosis of non-classical form of congenital adrenal dysfunction is an increase the level of 17-OH-progesterone and in some cases to confirm this diagnosis, genetic research methods can be used $[8,18]$.

The results of the assessment of the concentration of hormones in the blood of women in the study groups are presented in table. Statistically significant $(\mathrm{p}<0,05)$ predominance in the main group compared with the control group was established by the level of An, Tf and its index, as well as 17-OHP and Pr. However, about 17-OHP and $\mathrm{Pr}$, their indicators were within the reference values of the norm in all women in the study groups.

Free and total testosterone are known to have relatively low sensitivity, and among the most informative indicators in the diagnosis of HA, according to the recommendations of the European Endocrine Society (ESS), are the free testosterone index and androstenedione. It should be noted that the study of androgen levels is an auxiliary method for diagnosis and in any case should not be used as the main criterion or substitute for clinical diagnosis of PCOS [8].

There are 4 phenotypes (clinical variants) of PCOS: phenotype A (classical), which is characterized by chronic anovulation, hyperandrogenism, polycystic ovary transformation (according to ultrasound); phenotype B (incomplete classical or anovulatory): hyperandrogenism and oligoanovulation (without ultrasound signs of polycystic ovarian morphology); phenotype C (ovulatory): hyperandrogenism and polycystic ovarian morphology (according to ultrasound) on the background of regular ovulatory cycles; phenotype D (non-androgenic): chronic anovulation and polycystic ovary transformation (according to ultrasound) without clinical / biochemical hyperandrogenism $[2,4,8,9]$.

Analyzing the frequency of phenotypes (clinical variants) of PCOS, it was found (Pic. 3) that phenotype A (classical) occurred in $32,4 \%$. Phenotype B (incomplete classical) was diagnosed in $14,7 \%$, and phenotype C (ovulatory) in only $8,8 \%$.

The most often, namely in $15(44,1 \%)$ women with PCOS, the phenotype D (non-androgenic) was established.
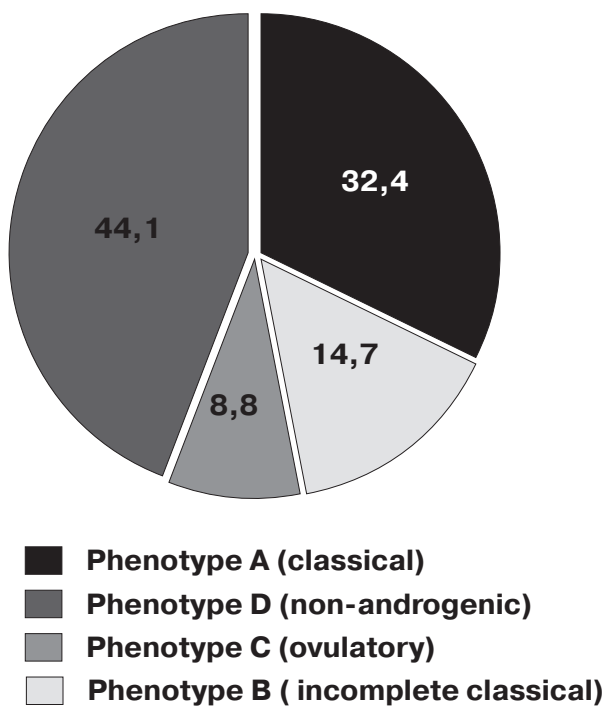

Pic. 3. The frequency of phenotypes (clinical variants) of PCOS, \%

\section{CONCLUSIONS}

1. The results of the conducted research show that in women with PCOS clinical symptoms are characterized by menstrual dysfunction $(73,5 \%)$, infertility $(52,9 \%)$ and dermatopathies, namely acne $(47,1 \%)$ and hirsutism $(41,2 \%)$.

2. In the group of women with PCOS it was found a statistically significant $(\mathrm{p}<0,05)$ predominance of the level of androstenedione, free testosterone and its index $(\mathrm{An}-3,2 \pm 0,2 \mathrm{ng} / \mathrm{ml}, \mathrm{Tf}-$ $4,1 \pm 0,6 \mathrm{pg} / \mathrm{ml}$ and TF index $-2,8 \pm 0,4 \%$, respectively) compared with the control group (An - 1,7 $\pm 0,2 \mathrm{ng} / \mathrm{ml}$, Tf $-1,9 \pm 0,2 \mathrm{pg} / \mathrm{ml}$ and TF index $-1,3 \pm 0,2 \%$, respectively).

3. Among the clinical variants of PCOS, the most often diagnosed was non-androgenic phenotype (phenotype D), the frequency of which was $44,1 \%$. Classical (phenotype A) and incomplete classical (phenotype B) were established in $32,4 \%$ and $14,7 \%$, respectively. It should be noted that only $8,8 \%$ women with PCOS were diagnosed with phenotype C (ovulatory).

\section{Information about the author}

Syusyuka Volodymyr G. - Department of Obstetrics and Gynecology, Zaporizhzhia State Medical University, 69035, Zaporizhia, 26 Mayakovsky Ave.E-mail:svg.zp.ua@gmail.com

Sergienko MarynaY. - Department of Obstetrics and Gynecology, Zaporizhzhia State Medical University, 69035, Zaporizhia, 26 Mayakovsky Ave.

Makurina Galyna I. - Department of Dermatovenereology and Cosmetology with a course of dermatovenereology and aesthetic medicine FPE, Zaporizhzhia State Medical University, 69035, Zaporizhia, 26 Mayakovsky Ave.

Yershova Olena A. - Department of Obstetrics and Gynecology, Zaporizhzhia State Medical University, 69035, Zaporizhia, 26 Mayakovsky Ave.

Chornenka Alona S. - Department of Dermatovenereology and Cosmetology with a course of dermatovenereology and aesthetic medicine FPE, Zaporizhzhia State Medical University, 69035, Zaporizhia, 26 Mayakovsky Ave.

\section{Відомості про авторів}

Сюсюка Володимир Григорович - Кафедра акушерства і гінекології Запорізького державного медичного університету, 69035, м. Запоріжжя, пр-т Маяковського, 26. E-mail:svg.zp.ua@gmail.com

Сергієнко Марина Юріївна - Кафедра акушерства і гінекології Запорізького державного медичного університету, 69035, м. Запоріжжя, пр-т Маяковського, 26

Макуріна Галина Іванівна - Кафедра дерматовенерології та косметології з курсом дерматовенерології і естетичної медицини ФПО Запорізького державного медичного університету, 69035, м. Запоріжжя, пр-т Маяковського, 26

Єршова Олена Андріївна - Кафедра акушерства і гінекології Запорізького державного медичного університету, 69035, м. Запоріжжя, пр-т Маяковського, 26

Чорненька Альона Сергіївна - Кафедра дерматовенерології та косметології з курсом дерматовенерології і естетичної медицини ФПО Запорізького державного медичного університету, 69035, м. Запоріжжя, пр-т Маяковського, 26 


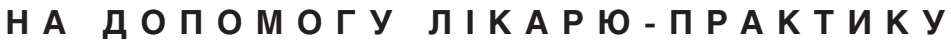

\section{Сведения об авторах}

Сюсюка Владимир Григорьевич - Кафедра акушерства и гинекологии Запорожского государственного медицинского университета, 69035, г. Запорожье, пр-т Маяковского, 26. E-mail: svg.zp.ua@gmail.com

Сергиенко Марина Юрьевна - Кафедра акушерства и гинекологии Запорожского государственного медицинского университета, 69035, г. Запорожье, пр-т Маяковского, 26

Макурина Галина Ивановна - Кафедра дерматовенерологии и косметологии с курсом дерматовенерологии и эстетической медицины ФПО Запорожского государственного медицинского университета, 69035, г. Запорожье, пр-т Маяковского, 26

Ершова Елена Андреевна - Кафедра акушерства и гинекологии Запорожского государственного медицинского университета, 69035, г. Запорожье, пр-т Маяковского, 26

Чёрненькая Алёна Сергеевна - Кафедра дерматовенерологии и косметологии с курсом дерматовенерологии и эстетической медицины ФПО Запорожского государственного медицинского университета, 69035, г. Запорожье, пр-т Маяковского, 26

\section{REFERENCES}

1. Абашова Е.И., Шалина М.А., Мишарина Е.В., Ткаченко Н.Н., Булгакова О.Л. Клинические особенности фенотипов синдрома поликистозных яичников у женщин с нормогонадотропной ановуляцией в репродуктивном возрасте // Журнал акушерства и женских болезней. 2019; 68, 3: 7-14.

2. Авраменко Н.В., Кабаченко О.В. Барковський Д.Є., Сєрих К.В. Сучасні аспекти менеджменту пацієнток із синдромом полікістозу яечників. Запорізький медичний журнал. 2020; 22, 6 (123): 865-873.

3. Блесманович А.Е., Петров Ю.А., Алехина А.Г. Сидром поликистозных яичников: классика и современные нюансы. Health and Education Millennium. 2018; 20, 4: 33-37.

4. Бурка О.А., Тутченко Т.М. Сучасні підходи до діагностики розповсюджених форм гіперандрогенії в жінок репродуктивного віку. Репродуктивна ендокринологія. 2019; 2 (42): 39-45.

5. Жабіцька Л.А. Синдром полікістозних яєчників: індивідуалізований підхід до лікування. Огляд літератури. Репродуктивна ендокринологія. 2020; 4 (54): 89-94.

6. Заславский Д.В., Прокопенко А.Д., Даниелян Д.А. Дерматологический аспект значения гиперадрогении при синдроме поликистозных яичников. Современные проблемы науки и образования. 2018; 4. URL: http:// www.science-education.ru/ru/article/ view?id=27777

7. Калугіна Л.В., Татарчук Т.Ф. Синдром полікістозних яєчників: підхід до корекції метаболічних порушень. Репродуктивна ендокринологія. 2020; 2 (52): 54-58.

8. Камінський В.В., Татарчук Т.Ф., Дубоссарська Ю.О. та ін. Національний консенсус щодо ведення пацієнток із гіперандрогенією. Репродуктивна ендокринологія. 2016; 4 (30): 19-31.

9. Коркан А.И., Туреханова А.Д., Тюгай Ю.Л. Современные методы лечения синдрома поликистозных яичников (обзор литературы). Репродуктивная медицина. 2020; 1 (42): 27-34.
10. Сутурина Л.В. Синдром поликистозных яичников в XXI веке. Акушерство и гинекологи: новости, мнения, обучение. 2017; 3: 86-91.

11. Урбанович А.М. Синдром полікістозних яєчників у щоденній практиці. Міжнародний ендокринологічний журнал. 2018; 14, 1: 40-45.

12. Чечуга С.Б. Гормональна фармакотерапія при синдромі полікістозних яєчників. Репродуктивная медицина. 2019; 1 (45): $52-56$

13. Baskind N.E., Balen A.H. Hypothalamic-pituitary, ovarian and adrenal contributions to polycystic ovary syndrome. Best Practice \& Research Clinical Obstetrics \& Gynaecology. 2016; 37: 80-97. 14. International evidence-based guideline for the assessment and management of polycystic ovary syndrome 2018 / Centre for Research Excellence in Polycystic Ovary Syndrome (CREPCOS), European Society of Human Reproduction and Embryology (ESHRE), American Society of Reproductive Medicine (ASRM). Monash University, 2018. 198p.
15. Legro R.S., Arslanian S.A. Ehrmann D.A. et al. Diagnosis and treatment of polycystic ovary syndrome: an Endocrine Society clinical practice guideline. J Clin Endocrinol Metab. 2013; 98 (12): 456592.

16. Pakharenko L.V., Vorobii V.D., Kurtash N.Ya., Perkhulyn O.M. Assessment of quality of life among women with polycystic ovary syndrome of different reproductive age. Zaporozhye medical journal. 2019; 21 (1): 100-103.

17. Rotterdam ESHRE/ASRM-Sponsored PCOS consensus workshop group. Revised 2003 consensus on diagnostic criteria and long-term health risks related to Polycystic Ovary Syndrome (PCOS). Hum Reprod. 2004 19(1): 41-47.

18. Speiser P.W., Arlt W., Auchus R.J. et al. Congenital Adrenal Hyperplasia Due to Steroid 21-Hydroxylase Deficiency: An Endocrine Society. Clinical Practice Guideline. The Journal of Clinical Endocrinology \& Metabolism. 2018; 103, 11: 4043-4088. 